\title{
Variance of Granular Morphology in Kithul (Caryota urens) Flour among Five Different Growing Areas in Sri Lanka
}

\author{
${ }^{1} \mathrm{~J}$ A A C Wijesinghe, ${ }^{1} \mathrm{I}$ Wicramasinghe and ${ }^{2} \mathrm{~K}$ H Saranandha \\ ${ }^{1}$ Department of Food Science \& Technology, University of Sri Jayewardenepura, Sri Lanka \\ ${ }^{2}$ Food Research Unit, Gannoruwa, Sri Lanka
}

\begin{abstract}
Kithul (Caryota Urens) palm is a useful tree in Sri Lanka being the sap is used as an ingredient for a large number of foods. Kithul flour also will be a good ingredient having considerable gelling property. The objectives of this study were to analyze the granular morphology of Kithul flour and study differences among flour samples from five main Kithul growing areas. Flour samples were collected from both household and commercial markets representing five main Kithul growing districts: Rathnapura, Kegalle, Kandy, Matale and Kurunegala. Microscopic measurement of starch granules was done using light microscope under the magnification power of $400 x$ with Magnus live USB 2.0 viewer and Image tool for windows softwar). Flour treatments did not differ with respect to granular morphology with mean length and width of starch granule being $45.5 \mu \mathrm{m}, 26.4 \mu \mathrm{m}$, respectively. This study showed different shapes of Kithul starch granules such as spherical, oval, and irregular globular with oval shape being the most common shape (51.4\% of total granules). Analyzed results revealed that there were no significant differences among Kithul flour samples obtained from five main growing districts with respect to granular morphology which could be a positive point for using composite Kithul flour from different growing areas for future food applications.
\end{abstract}

KEYWORDS: Kithul flour, Caryota urens, granular morphology, granular shape, Kithul growing areas

Corresponding author: J. A. A. C. Wijesinghe, eMail: lucky.research@yahoo.com 


\section{INTRODUCTION}

Starch is the storage form of plant carbon assimilation (Vegh, 2002) formed by complex series of biochemical reaction of photosynthesis (Qiang, 2005). Starch is composed of amylose and amylopectin which are molecular entities of polysaccharide (Qiang, 2005). Differences in physico-chemical properties of these two molecules affect retrogradation, viscosity, and gel stability properties of starch (Vegh, 2002) The ratio of amylose:amylopectin in starch granules differ based on plant origin. Starch consists of alternating semi-crystalline and amorphous layers (Svilhus et al., 2005)

Type of starch as well as the amount of starch are important factors for the final texture of the food product (Biliaderis, 1991) .The shape and size of the granules are important factors for the functional properties of the starch (Svilhus et al., 2005), especially swelling, solubility and digestibility (Adejumo et al., 2011) Franco \& Ciacco, (1992) observed that the large size of starch granule are responsible for less of enzymatic susceptibility (Franco \& Ciacco, 1992)

Diameter of starch granule, recently, has been found to be an essential component for food and industrial applications of starches (Campbell et al., 1996). Granule distribution varies between cultivars according to the genetically controlled (Sahlstrom et al., 1998) and environmental factors (Testeret et al., 1991). However, granular morphology is very effective for identification of botanical source because shape, size and hilum position (Qiang, 2005) of the granules depend on the source (Preiss, 2004). As the main energy of human diet starch plays a major role. It creates a high demand for new starch source as staple food for boost population all over the world. Hence food and agro- researchers are discovering novel sources of starch, which exist in the wild. Kithul (Caryota urens) is an agreeable feedback for this requirement, which is still kept as a semi-wild species.

Kithul (Caryota urens) is indigenous to India, Sri Lanka and Malaysia (Rajyalakshmi, 2004), while the most prominent trees in the perennial forests of highland Sri Lanka (Ynonne, 1995). It is a slow-growing, shadetolerant (Orwa et al., 2009) palm. The total number of Kithul trees found in the island amounts to 2,977,261 (largely spread in Sabaragamuwa, Central and Uva provinces), which has surveyed by National programme for Kithul Development, Ministry of traditional industries and small enterprise development (Ministry of Traditional Industries, 2009. This palm comes under the commercially beneficial trees in Sri Lanka, being used to produce large number of food and wooden products. Kithul flour is used as a main ingredient for a large number of foods (Punchihewa, 2012) such as pudding (thalapa), porridge (Kenda), rice cake (kawum), a sweet meat (Dodol) and dough of flour heated in a pan (Rotee) etc (Seneviratne, 2011).

As per the literature, palm starch is one of the cheapest and most available sources of food, which shows the highest productivity per land area among other starch crops (Shoon, 2000).

The objectives of this study were to analyze the granular morphology of Kithul flour and study differences among flour samples from five main Kithul growing areas to find out the possibilities to use Kithul flour from any growing area for future food applications.

\section{MATERIALS \& METHODS}

\subsection{Selection of area and sample collection}

Areas were selected based on the statistics on Kithul palms by district. Five districts, namely Kurunegala (North-western 
province), Matale and Kandy (Central province), and Kegalle and Rathnapura (Sabaragamuwa province) were selected for the study as the five main growing area in Sri Lanka. Six Kithul flour samples were collected from each district from both household and commercial markets.

\subsection{Granular morphological variations of starch}

Morphology of native starch granules was observed according to the method described by Jayakody et al, 2009 with slight modifications. Starch solution was prepared by mixing with $1: 1(\mathrm{w} / \mathrm{v})$ mixture of distilled water to glycerine $(1: 1, \mathrm{v} / \mathrm{v})$. The starch solution was stained with a $0.05 \%$ iodine solution and a thin smear was prepared on a glass slide with a cover slip. Microscopic measurement of Kithul starch granules was done using light microscope (HITACHI SU 6600, Japan) under the magnification power of $400 \mathrm{x}$ with Magnus live USB 2.0 viewer and UTHSCSA Image tool for windows software (Developed by University of Texas, 1995-2002). The length and diameter of the granules from each starch sample obtained from five different districts were measured and the shape of granules was observed.

\subsection{Statistical Analysis}

Results were analyzed using one-way analysis of variance (ANOVA) at 0.05 probability level with MINITAB software package (version 14 for Windows)

\section{RESULTS AND DISCUSSION}

According to the statistical results of the starch granular length and width there were no any significant differences $(p>0.05)$ among samples from five districts (Table 1). Length of the granules ranged from 9.8 to $117.8 \mu \mathrm{m}$ though mean value was $45.6 \mu \mathrm{m}$ (Figure 1), which is compatible with previously reported value $(44 \mu \mathrm{m})$ of Caryota urens pith flour (Anilakumai \& RajyalakshmI, 2000), while the width of granules ranged from 7.0 to $56.9 \mu \mathrm{m}$ with a mean value of $26.4 \mu \mathrm{m}$ (Table 1).

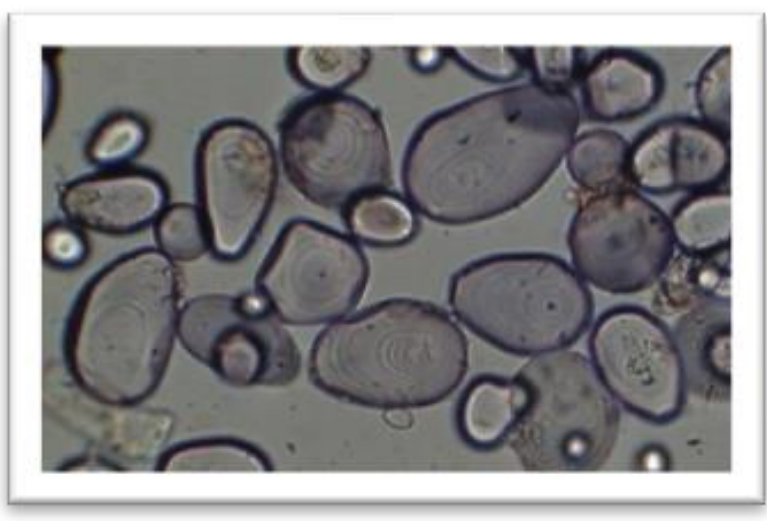

Figure1. Light micrograph $(\mathrm{x} 400)$ of different size of Kithul starch granules

Table 1. Variations in granular size of Kithul flour collected from five districts in Sri Lanka

\begin{tabular}{|l|l|l|}
\hline \multicolumn{1}{|c|}{ Sampling Area } & $\begin{array}{c}\text { Length of } \\
\text { the granule / } \\
\boldsymbol{\mu m}\end{array}$ & $\begin{array}{c}\text { Width of the } \\
\text { granule / } \boldsymbol{\mu m}\end{array}$ \\
\hline Kandy & $47.8 \pm 20.3^{\mathrm{a}}$ & $26.4 \pm 11.0^{\mathrm{a}}$ \\
\hline Kegalle & $45.1 \pm 16.7^{\mathrm{a}}$ & $29.0 \pm 10.8^{\mathrm{a}}$ \\
\hline Kurunegala & $44.0 \pm 20.5^{\mathrm{a}}$ & $23.9 \pm 8.4^{\mathrm{a}}$ \\
\hline Matale & $45.1 \pm 19.4^{\mathrm{a}}$ & $25.5 \pm 9.4^{\mathrm{a}}$ \\
\hline Rathnapura & $45.8 \pm 19.0^{\mathrm{a}}$ & $27.0 \pm 9.5^{\mathrm{a}}$ \\
\hline Mean & $45.6 \pm 19.1$ & $26.4 \pm 9.9$ \\
\hline
\end{tabular}

According to the literature there is no special categorization of granule size (Lindebooma et al., 2004). Adejumo et al., 2011 has defined the following classes based on granular size: large $(25 \mu \mathrm{m})$, medium $(10-25$ $\mu \mathrm{m})$, small $(5-10 \mu \mathrm{m})$ and very small $(<5 \mu \mathrm{m})$ granules Based on this classification Kithul starch granules can be considered large as granular size falls within the range of 26-47 $\mu \mathrm{m}$. Reported data of Cornell et al. (1994) exhibited that granule size may vary from 1-50 $\mu \mathrm{m}$. When compared with the typical granule size of commercially available starch sources as $22 \mu \mathrm{m}$ for wheat starch, $8 \mu \mathrm{m}$ for rice starch and $38 \mu \mathrm{m}$ for potato starch (Cornell et al., 
1994), Kithul starch has the highest value as $45.6 \mu \mathrm{m}$. According to Qiang Liu (2005), size of starch granules vary from 2-100 $\mu \mathrm{m}$ and most cereal starch granules are smaller than tuber and legume starches (Qiang.L,2005). Sago flour produced similarly from the bark of Metroxylon sagu tree exhibited a granular size of $28.4 \mu \mathrm{m}$ (Yiu,P.H et al,2008)

Kithul starch granules exhibited three main granular shapes, namely spherical, oval an irregular globular shape (Figure 2). But five Kithul flour treatments did not show significant differences with respect to distribution of the three shapes (Table 2). The most common shape among samples from all five districts was oval shape (Percentage of granules ranging from 45.0 to $57.5 \%$ ) (Table 2). Some granules exhibit their shape smoothly, while others are polyhedrons with a faceted surface (Vegh, 2002).

Granule shape is a very important characteristic to identify uniqueness of the starch. According to literature maize starch granules exhibited round and polygonal shapes while rice granule has polygonal shape, wheat granules has round and lenticular shapes and potato granules presented voluminous, oval and oyster shapes (Blandhard, 1987, Promanz, 1985 and Hoover, 2001). In the case of sago flour granular shape has been reported as oval, truncated (Sighal et al., 2008)

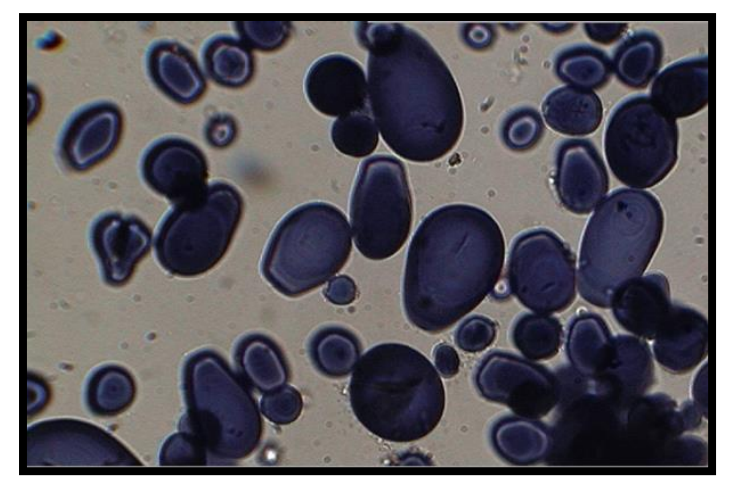

Figure 2. Light micrograph (x400) of different shapes of Kithul starch granules as spherical, oval and irregular globular
Table 2. Variations on Granular shapes of Kithul flour collected from five districts in Sri Lanka

\begin{tabular}{|l|l|l|l|}
\hline $\begin{array}{c}\text { Sampling } \\
\text { Area }\end{array}$ & $\begin{array}{c}\text { Spherical } \\
\text { shape \% }\end{array}$ & $\begin{array}{c}\text { Oval shape } \\
\%\end{array}$ & $\begin{array}{c}\text { Irregular } \\
\text { globular } \\
\text { shape \% }\end{array}$ \\
\hline Kandy & $22.9 \pm 16.5^{\mathrm{a}}$ & $57.5 \pm 14.1^{\mathrm{a}}$ & $19.6 \pm 15.5^{\mathrm{a}}$ \\
\hline Kegalle & $35.7 \pm 19.7^{\mathrm{a}}$ & $52.3 \pm 21.4^{\mathrm{a}}$ & $12.0 \pm 10.2^{\mathrm{a}}$ \\
\hline Kurunegala & $45.4 \pm 18.7^{\mathrm{a}}$ & $45.0 \pm 16.2^{\mathrm{a}}$ & $9.6 \pm 6.3^{\mathrm{a}}$ \\
\hline Matale & $38.3 \pm 17.9^{\mathrm{a}}$ & $46.5 \pm 11.0^{\mathrm{a}}$ & $15.2 \pm 11.6^{\mathrm{a}}$ \\
\hline Rathnapura & $33.35 \pm 9.0^{\mathrm{a}}$ & $55.6 \pm 6.4^{\mathrm{a}}$ & $11.0 \pm 9.2^{\mathrm{a}}$ \\
\hline Mean & $35.1 \pm 17.3$ & $51.4 \pm 14.6$ & $13.5 \pm 10.8$ \\
\hline
\end{tabular}

\section{CONCLUSION AND FURTHER WORK}

Granular morphology studies confirmed that there was no significant difference among Kithul flour samples from five districts, and mean value of the starch granular length and width were $45.6 \pm 19.1$ and $26.4 \pm 9.9 \mu \mathrm{m}$, respectively. Three types of granular shapes: Oval, spherical and irregular globular shapes were exhibited. Most common shape was oval which represented $51.4 \pm 14.6$ $\%$ of granules. Spherical shape got the second representative percentage contributing $35.1 \pm$ $17.3 \%$ of granular shape while irregular globular shape had lowest value as $13.5 \pm$ $10.8 \%$.

According to this study, there were no significant differences among Kithul flour samples obtained from five main growing districts with respect to granular morphology which could be a positive point for using composite Kithul flour from different growing areas for future food applications.

\section{ACKNOWLEDGEMENT}

The authors thank the University of Sri Jayewardenepura, Sri Lanka for financial assistance (Grant No: ASP/06/RE/SCI/2012/04). Authors are grateful to Dr. M.A.P.K Seneviratne, Department of Export Agriculture, District office, Peradeniya for assisting in classification of Kithul growing area. 


\section{REFERENCE}

ADEJUMO A, ADERIBIGBE AF \& LAYOKUN SK. Cassava Starch: Production, Physicochemical Properties and Hydrolysation- A Review. Adejumo et al / Advances in Food and Energy Security 2. 2011.

ANILAKUMAI B, \& RAJYALAKSHMI P. Qualitative aspects, product suitability and in vitro starch digestibility of caryota palm sago-An uncommon food tribals. J.Food Sci.Technol. 2000; 37(1): 75-78.

BILIADERIS CG. The structure and interaction of starch with food constituents, Can J physiol pharmacol. 1999; 69, 60-78.

BLANSHARD JMV. Starch granule structure and function: a physicochemical approach. Starch: Properties and Potential. Ed. T. Galliard. John Wiley \& Sons. Chichester, U.K. 1987; 17-54.

Campbell MR, Li J, Berke TG \& Glover D V. Variation of Starch Granule Size in Tropical Maize Germ Plasm. Cereal Chem. American Association of Cereal Chemists, Inc. 1996; 73(5):536-538.

Cornell HJ, Hoveling AW, Chryss A, Rogers M. Particle size distribution in wheat starch and its importance in processing. Starch. 1994; 46: 203-207.

Franco CML \& Ciacco CF. Factors that Affect the Enzymatic Degradation of Natural Starch Granules. Effect of the Size of the Granules. Starch/Stärke. 1992; 44: 422-426.

Hoover R. Composition, molecular structure, and physicochemical properties of tuber and root starches: a review. Carbohydrate Polymers. 2001; 45: 253-267.

Jayakody SWP. Evaluation of Physiochemical properties and morphology of trarches of Kithul (Caryota urens), Kuru Kithul(caryota plumose) and their hybrid, Unpublished Bsc thesis, Dept. of Food Science \& Technology, University of Peradeniya. 2009; 4-27.
Lindebooma N, Chang PR \& Tylera R T. Analytical, Biochemical and Physicochemical Aspects of Starch Granule Size, with Emphasis on Small Granule Starches: A Review. Starch/Stärke. 2004; 56: 89-99.

ORWA C, MUTUA A, KINDT R, JAMNADASS R, SIMONS A, ARECACEAE L. Caryota urens. Agroforestree Database: a tree reference and selection guide version 4.0. Available from: http://www.worldagroforestry.org/af/treedb/2 009. (Accessed on 2013.10.02).

Pomeranz Y. Functional Properties of Food Components. Academic Press, Inc., Orlando, FL. 1985.

Preiss J. Plant starch synthesis. In: Eliassion A. C. Starch in food: structure, function and applications Cambridge and New York: Woodhead Publishing Limited and CRC Press LLC. 2004; 3-56.

Punchihewa SP. Kitul industry in Sri Lanka; on April 16, 2012. Available From: urlaub-srlanka.info; www.urlaub-sr-lanka.info/srilanka-holiday/2012/04/kitul+industry+in +Sri +Lanka.htm. (Accessed on 2013.12.01)

Qiang L. Chemistry,physical properties and applications, Food carbohydrates (Steve W . Cui), CRC press, ISBN:978-0-8-493-15749,DOI: 10.1201/9780203485286.ch7. 2005.

Rajyalakshmi P. Caryota palm sago O A potential get underutilized natural resource for modern starch industry. Naturakl product redience. 2004; 3(3): 144 -149.

Sahlstr"om S, Br ${ }^{\circ}$ athen E, Lea P, Autio K. Influence of starch granule size distribution on bread characteristics.J. Cereal Sci. 28, 157-164.

Seneviratne MAPK. Unpublished phd thesis on "Utilization of indigenous knowledge for the uplistment of Kithul in Sri Lanka. 2011; 219, 217-222.

Shoon Jong. Rain forest gifts; Sago \& sago grubs. 2000. Available from: Www.2000szgdocentorg/ff/f-sago.htm.

(Accessed on 08.08.2013). 
Singhal RS, Kennedy JF, Gopalakrishnan SM, Kaczmarek A, Knill CJ, Akmar PF. Industrial production, processing, and utilization of sago palm-derived products, Carbohydrate Polymers. 2008; 72: 1-20.

Statistic on Kithul palms in Sri Lanka; National programme for Kithul Development, Ministry of traditional industries and small enterprise development. 2009; 3-7.

Svihus B, Uhlen AK, Harstad OM. Effect of starch granule structure, associated components and processing on nutritive value of cereal starch: A review, Elsevier; Animal Feed Science and Technology. 2005; 122: 306, 303-320.

Tester RF, South JB, Morrison WR, Ellis RP. The effects of ambient temperature during the grain-filling period on the composition and properties of four barley genotypes. J. Cereal Sci. 1991; 13:113-127.

Vegh KR. Starch bearing crops as food sources, Cultivated plants primarily as food sources. 2002; vol. I. ISBN: 978-1-84826100-6 (eBook) http://www.eloss.net/ElosssampleAllChapter.aspx.

Yiu PH, Loh SL, Rajan A, Wong SC \& Bong CFJ. Physiochemical Properties of Sago Starch Modified by Acid Treatment in Alcohol, American Journal of Applied Sciences. ISSN 1546-9239.2008; 5 (4): $307-$ 311.

Yvonne Everett. The Kitul Palm: Ethnobotany of Caryota Urens L. In Highland Sri Lanka. J. Ethnobiol. 1995; 15(2):161-176. 